\title{
The Role of C-reactive Protein and Interleukin 6 in the Cases of Preeclampsia Associated with Obesity
}

\author{
IZABELLA PETRE ${ }^{\# \#, ~ M A R I U S ~ C R A I N A ~}{ }^{1}$, NICOLAE SUCIU2*, ALINA SISU3 ${ }^{3}$, RADU DUMITRU MOLERIU4\#, ROXANA OANCEA ${ }^{5 *}$, \\ DANIELA RADU6*, ALINA-ELENA AGOSTON-VAS ${ }^{2,7}$, ADRIAN COSMIN ILIE ${ }^{3}$ \\ ${ }^{1}$ Victor Babes University of Medicine and Pharmacy, Department XII, Discipline of Obstetrics and Gynecology, 2 Eftimie Murgu \\ Sq., 300041, Timisoara, Roamnia \\ ${ }^{2}$ Carol Davila University of Medicine and Pharmacy, Department of Obstetrics and Gynecology, Alessandrescu Rusescu Institute \\ for Mother and Child Care, 120 Lacul Tei, 020395, Bucharest, Romania \\ ${ }^{3}$ Victor Babes University of Medicine and Pharmacy, Department of Anatomy and Embryology, 2 Eftimie Murgu Sq., 300041, \\ Timisoara, Romania \\ ${ }^{4}$ West University of Timisoara, Faculty of Mathematics and Computer Science, Department of Mathematics, 4 Vasile Parvan Blvd., \\ 300223, Timisoara, Romania \\ ${ }^{5}$ Victor Babes University of Medicine and Pharmacy, Faculty of Dental Medicine, Department I, 2 Eftimie Murgu Sq., 300041, \\ Timisoara, Romania \\ ${ }^{6}$ Victor Babes University of Medicine and Pharmacy, Surgery Department,2 Eftimie Murgu Sq., 300041, Timisoara, Romania \\ ${ }^{7}$ Victor Babes University of Medicine and Pharmacy, 2 Eftimie Murgu Sq., 300041, Timisoara, Romania
}

\begin{abstract}
In the management of preeclampsia/eclampsia, it would be useful at least at European level, to have clear protocols for early detection and approach of cases with hypertension, as well as to create an algorithm to identify the predisposition to hypertensive pregnancy pathology. The aim has been to identify the favorable factors and the evolution of the pregnancy in the 100 patients admitted to the obstetrics clinic between January 2014 and December 2018, aged between 15-44 years, who have been diagnosed with preeclampsia. In recent years, the management of pregnant women with preeclampsia has improved a lot due to a better understanding of the pathogenesis and a refinement of adequate pregnancy monitoring. Obesity has been shown to be a risk factor in preeclampsia. Several studies have identified preeclampsia as an inflammatory condition. A large number of inflammatory markers, such as C-reactive protein (PCR) and Interleukin 6 (IL6), have been shown to be elevated in pregnant women with preeclampsia.
\end{abstract}

Keywords: Preeclampsia, Interleukin 6 (IL-6), body mass index (BMI), C-reactive protein (PCR)

Preeclampsia is a pregnancy-specific syndrome that occurs during the second trimester of gestation and is defined by the occurrence of hypertension (systolic blood pressure $>140 \mathrm{mmHg}$ and diastolic blood pressure $>90$ $\mathrm{mmHg}$ ) in a previously normotensive patient, accompanied by proteinuria ( $>0.3 \mathrm{~g} / 24 \mathrm{~h}$ ). Its etiology is unknown, and there are numerous studies, some of them contradictory, regarding the occurrence and risk factors of preeclampsia. Some studies indicate that placenta plays a key role in preeclampsia. The global preeclampsia prevalence is between 2-8\%.[1-6].

There are a number of risk factors that predispose to the occurrence of preeclampsia.

Obesity increases the overall risk of preeclampsia by approximately 2- to 3-fold. The risk of preeclampsia increases progressively with increasing BMI (body mass index), even in the normal range. It is important to know that both mild preeclampsia with elevated blood pressure and severe preeclampsia are associated with higher perinatal morbidity and mortality. Given the global obesity epidemic, the obesity is one of the most important risk factors for preeclampsia [7-8].

Some studies suggest that excessive increase maternal body weight is associated with risk of preeclampsia, although they may be confused with increasing fluid retention that contribute to weight gain, especially if there is another pathology (kidney disease, diabetes, hypertension preexisting pregnancy) [9-12].

Inflammation is a common feature of obesity, cardiovascular disease and preeclampsia.
Interleukin 6(IL-6) is a potent pre-inflammatory cytokine being involved in vascular inflammation and leakage, and is associated with obesity, insulin resistance, and subsequent cardiovascular disease.

IL-6 is secreted from adipose tissue into the circulation, and its expression is positively correlated with $\mathrm{BMI}$ and total fat tissue mass. Interleukin-6-deficient might develop mature-onset obesity

Adipose tissue generates several inflammatory mediators that can alter endothelial barrier function and are more active in obese people. C-reactive protein (CRP) is an acute inflammatory protein, manufactured by the liver and adipocytes is higher in obese individuals and is associated with cardiovascular morbidity. Circulating CRP is elevated early in pregnancy prior to the development of preeclampsia and appears to have a stronger association with pre-eclampsia in obese women.

\section{Experimental part \\ Material and method}

In this case control study we analyzed 200 patients having the age between 15 years and 44 years. We split the database in two homogeneous groups. The first group contains patients who developed preeclampsia during pregnancy (study group, N1=100 patients) and in the second group we have heathy patients who had a normal development during pregnancy (control group, N2=100 patients). For the statistical analysis we used a Mann Whitney test, a $\chi^{2}$ test for proportions, a risk analysis and a 
correlation and regression analysis using the SPSS, Microsoft Excel and Epi Info programs.

\section{Results and discussions}

The association between the risk of preeclampsia and obesity has also been demonstrated in different populations worldwide [13-15].

IL-6 is a potent pre-inflammatory cytokine being involved in vascular inflammation and leakage, and is associated with obesity, insulin resistance, and subsequent cardiovascular disease. Circulating concentrations are also higher with obesity and with preeclampsia, indicating a potential link [16-22].

In order to prove the main ideas that characterize our study we run a statistical analysis upon our database. For this we took under consideration two equal samples. 100 patients who develop preeclampsia during pregnancy (the study group) and 100 patients who had a normal development during pregnancy (the control group). The two groups have the same main characteristics: age, parity and gestational period, but we registered differences regarding their BMI and the CRP and IL 6 values. So, further on we will analyze the database to see if this observed differences can be considered statistical significant.

First of all we run a distribution analysis, we applied a Kolmogorov - Smirnov test and we obtained that for all our variables we don'thave a normal distribution. So, based on this result we will use for our analysis only non - parametric tests.

As well we present a descriptive analysis for our data using the central tendency and dispersion indicators. From this tables we seen that beside the age and height variable the other variables register quit major differences (table $1)$.
After observing the results from the descriptive analysis we tested to see if this differences are statistically significant. For this we applied a Mann - Whitney test for the two studied groups upon all the numerical variables from our study. As we expected, beside the age and the height, where we don't have significant differences, all the other variables register extremely significant differences within the groups $(p<0.001)$ (table 2).The dynamics of the numerical data is plotted as well in figure 1 .

After seeing that there are major differences between the two groups we tested to see if a BMI higher than 30 can be considered a risk factor for developing preeclampsia. In our case we have a case control study, so we will calculate the odd ratio value and for the statistical significance we will apply a $\chi^{2}$ test for proportions and we will compute the $95 \%$ confidence interval for the odd ratio values. So based on this criteria we split our data base in four different subgroups: patients with or without preeclampsia and patients who have the BMI higher or less than 30. After running the risk analysis we obtained an extremely significant risk factor in developing preeclampsia if the $\mathrm{BMI}$ is higher than $30(\mathrm{OR}>1, \mathrm{p}<$ 0.001 ). All the data is presented in table 3 and plotted in figure 2 .

In the end of our analysis we run a regression analysis in order to see if there is an association between the BMI and the CRP and IL6. We obtained a positive extremely significant association between the BMI and the CRP values ( $\left.r=0.676 ; R^{2}=0.458 ; p<0.001\right)$. In the case of $B M I$ and IL 6 as well, we obtained a positive extremely significant association $\left(r=0.631 ; R^{2}=0.398 ; p<0.001\right)$.

Table 1

WE CALCULATED THE CENTRAL TENDENCY AND DISPERSION INDICATORS FOR BOTH GROUPS. THE STUDY GROUP IS HIGHLIGHTED WITH GREEN AND THE CONTROL GROUP WITH YELLOW

\begin{tabular}{|c|c|c|c|c|c|c|c|c|c|c|c|c|}
\hline Statistics & Age & Age & $\begin{array}{l}\text { Height } \\
\text { [cm] }\end{array}$ & $\begin{array}{l}\text { Height } \\
\text { [cm] }\end{array}$ & $\begin{array}{l}\text { Weight } \\
{[\mathrm{kg}]}\end{array}$ & $\begin{array}{l}\text { Weight } \\
{[\mathrm{kg}]}\end{array}$ & $\begin{array}{l}\text { BMI } \\
(\mathrm{Kg} / \mathrm{m} 2)\end{array}$ & $\begin{array}{l}\text { BMI } \\
(\mathrm{Kg} / \mathrm{m} 2)\end{array}$ & PRC & PRC & IL6 & IL6 \\
\hline Mean & 27.05 & 26.48 & 165.07 & 162.56 & 79.46 & 59.68 & 29.25 & 22.66 & 17.59 & 5.71 & 64.82 & 14.95 \\
\hline $\begin{array}{l}\text { Standard } \\
\text { Error }\end{array}$ & 0.70 & 0.58 & 0.63 & 0.65 & 1.21 & 0.86 & 0.47 & 0.35 & 0.36 & 0.13 & 3.74 & 2.89 \\
\hline Median & 24 & 26 & 167 & 163 & 78.5 & 58 & 30.70 & 22.27 & 17.24 & 5.27 & 81.3 & 2.9 \\
\hline Mode & 24 & 19 & 167 & 160 & 70 & 54 & 30.84 & 19.53 & 22.48 & 5.27 & 87.4 & 2.9 \\
\hline $\begin{array}{l}\text { Standard } \\
\text { Deviation }\end{array}$ & 7.04 & 5.79 & 6.33 & 6.49 & 12.06 & 8.63 & 4.68 & 3.54 & 3.57 & 1.33 & 37.38 & 28.87 \\
\hline $\begin{array}{l}\text { Sample } \\
\text { Variance }\end{array}$ & 49.54 & 33.50 & 40.13 & 42.11 & 145.34 & 74.52 & 21.86 & 12.50 & 12.73 & 1.76 & $\begin{array}{l}1397.0 \\
7\end{array}$ & $\begin{array}{l}833.3 \\
8\end{array}$ \\
\hline Kurtosis & -0.95 & 0.25 & 4.68 & 0.32 & -0.17 & 3.05 & -0.40 & 1.95 & -1.17 & 1.04 & -1.35 & 6.88 \\
\hline Skewness & 0.58 & 0.75 & 1.06 & -0.40 & 0.14 & 1.52 & -0.05 & 1.33 & -0.04 & 1.27 & -0.43 & 2.69 \\
\hline Range & 26 & 29 & 43 & 28 & 67 & 40 & 24.54 & 16.40 & 13.79 & 5.69 & 112.01 & 144.7 \\
\hline Minimum & 15 & 15 & 153 & 147 & 49 & 50 & 18.59 & 18.37 & 9.79 & 3.93 & 1.99 & 0.7 \\
\hline Maximum & 41 & 44 & 196 & 175 & 116 & 90 & 43.13 & 34.77 & 23.58 & 9.62 & 114 & 145.4 \\
\hline Sum & 2705 & 2648 & 16507 & 16256 & 7946 & 5968 & 2924.77 & 2265.65 & $\begin{array}{l}1758 . \\
97\end{array}$ & 571.3 & $\begin{array}{l}6482.4 \\
3 \\
\end{array}$ & $\begin{array}{l}1495 . \\
07\end{array}$ \\
\hline Count & 100 & 100 & 100 & 100 & 100 & 100 & 100 & 100 & 100 & 100 & 100 & 100 \\
\hline
\end{tabular}


Table 2

AFTER APPLYING THE MANN - WHITNEY TEST WE OBTAINED THAT THE WEIGHT, BMI, CRP AND IL6 ARE SIGNIFICANTLY HIGHER IN THE STUDY GROUP . THE SIGNIFICANT RESULTS ARE HIGHLIGHTED WITH GRAY

\begin{tabular}{|c|c|c|c|c|c|}
\hline Variables & Group & $N$ (volume) & Mean Rank & Sum of Ranks & p - values \\
\hline \multirow{3}{*}{ Age } & study & 100 & 100.38 & 10037.50 & \multirow{3}{*}{$p=0.976$} \\
\hline & control & 100 & 100.63 & 10062.50 & \\
\hline & Total & 200 & & & \\
\hline \multirow{3}{*}{ Height [cm] } & study & 100 & 111.59 & 11158.50 & \multirow{3}{*}{$p=0.07$} \\
\hline & control & 100 & 89.42 & 8941.50 & \\
\hline & Total & 200 & & & \\
\hline \multirow{3}{*}{ Weight [kg] } & study & 100 & 141.94 & 14193.50 & \multirow{3}{*}{$p<0.001$} \\
\hline & control & 100 & 59.07 & 5906.50 & \\
\hline & Total & 200 & & & \\
\hline \multirow{3}{*}{$\mathrm{BMI}(\mathrm{Kg} / \mathrm{m} 2)$} & study & 100 & 137.11 & 13710.50 & \multirow{3}{*}{$p<0.001$} \\
\hline & control & 100 & 63.90 & 6389.50 & \\
\hline & Total & 200 & & & \\
\hline \multirow{3}{*}{ CRP } & study & 100 & 150.50 & 15050.00 & \multirow{3}{*}{$p<0.001$} \\
\hline & control & 100 & 50.50 & 5050.00 & \\
\hline & Total & 200 & & & \\
\hline \multirow{3}{*}{ IL6 } & study & 100 & 140.32 & 14032.00 & \multirow{3}{*}{$p<0.001$} \\
\hline & control & 100 & 60.68 & 6068.00 & \\
\hline & Total & 200 & & & \\
\hline
\end{tabular}
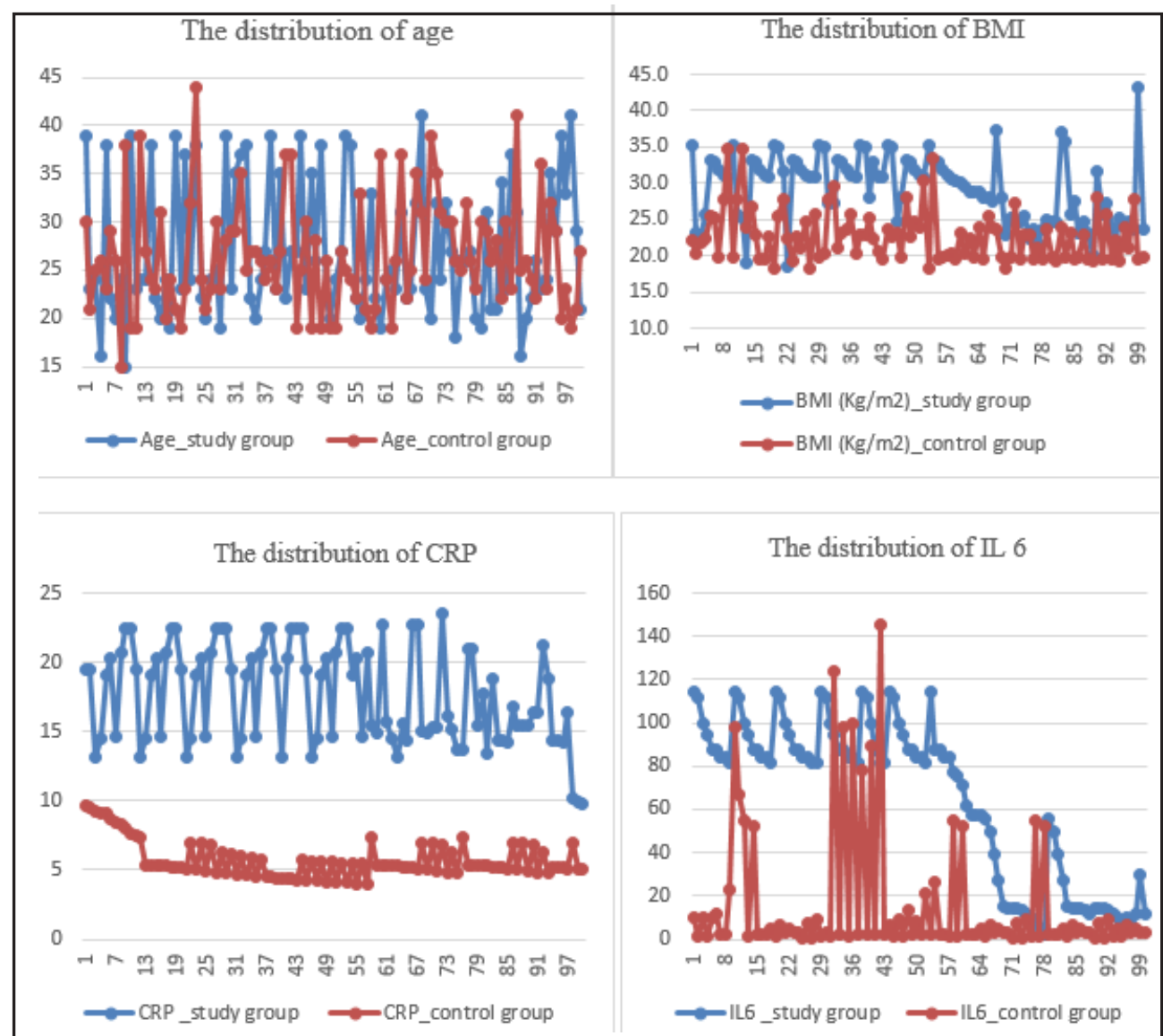

Fig. 1. We plotted the distribution of the most important variables from our study within the two groups

\begin{tabular}{|l|l|l|l|l|}
\hline & Preeclampsia+ & Preeclampsia- & Total & Statistics \\
\hline BMI $=30$ & 53 & 4 & 57 & $\mathrm{p}=0.001$ \\
\hline $\mathrm{BMI}=\mathbf{3 0}$ & 47 & 96 & 143 & $\mathrm{OR}=2.82$ \\
\hline Total & 100 & 100 & 200 & $\mathrm{OR}=(2.21 ; 3.61)$ \\
\hline
\end{tabular}

Table 3

WE PRESENTED THE CONTINGENCY TABLE FOR OUR STUDY AND WE APPLIED A $\chi^{2}$ TEST FOR PROPORTIONS AND WE CALCULATED THE ODD RATIO INDICATOR AND THE ODD RATIO 95\% CONFIDENCE INTERVAL 


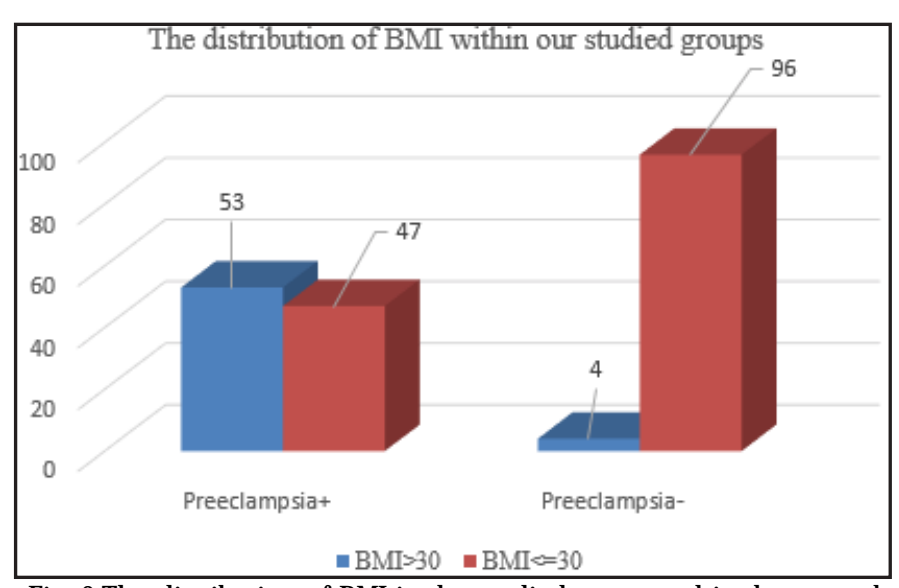

Fig. 2.The distribution of BMI in the studied group and in the control group. The threshold value for the BMI is the value of 30

\section{Conclusions}

Obesity has been shown to be a risk factor in preeclampsia. Several studies have identified preeclampsia as an inflammatory condition. A large number of inflammatory markers, such as PCR and IL-6, have been shown to be elevated in pregnant women with preeclampsia. More recentstudies establish an association between obesity and elevated levels of inflammatory markers, suggesting that obesity is an inflammatory disease or predisposes to a pro-inflammatory state. Although weight loss is discouraged during pregnancy, obesity is a potentially modifiable risk factor for preeclampsia. Along with obesity, maternal plasma concentrations of IL-6 play a significant role in the pathogenesis of preeclampsia

\section{Refrences}

1.TOTH G., ANASTASIU D., CRAINA M., CIRLOGEA A., MOLERIU R.D., CITU I., CITU C., IONITA I., PETRE I., First Trimester Screening for Preeclampsia, the $13^{\text {th }}$ Conference of the Romanian-German Society of Obstetrics and Gynecology, Timisoara, Romania, pp. 304-309, Ed. Filodiritto Editore Proceeding, ISBN 978-88-95922-95-9.

2.TOTH G., PETRE I., CRAINA M., MOLERIU R.D., BOGLUT A., IACOB D., IONITA I., MILOICOV O. BACEAN C., Paraclinical Correlations and the Macroscopic Aspect of Placenta in Cases of HTAIS Diagnosis, $5^{\text {th }}$ Congress of The Romanian Society of Ultrasound in Obstetrics and Gynecology, Filodiritto Editore Proceeding, Targu Mures, Romania, pp. 482-486, ISBN 978-88-95922-88-1.

3.IVAN, M.V., PETRE, I., VLAICU, B., APOSTOL, A., TESLOIANU, D., MUNTEANU, M., COSTACHESCU, R., MOLERIU, L.C., LAZAR, F., The Use of Pulse Wave Velocity in Predicting Pre-Eclampsia in High-Risk Women, Rev. Chim. (Bucharest), 69, no. 5, 2018, p. 1260-1263 4.MLADIN-MICOARA N.C., LUNGEANU D., MORARIU S.I., CIACLI C.A., MOLERIU L.C., STELEA L., PETRE I., IONITA I., CALAMAR-POPOVICI D., PUSCHITA M., Biomarkers in Diagnosing Preeclampsia and their Correlation with Blood Pressure, Rev. Chim. (Bucharest), 68, no. 10, 2017, p. 2449-2501

5.PETRE I., CRAINA M., CHIRIAC V.D., STELEA L., MOLERIU L. C., POP E., IURCIUC M., STOIAN D., IVAN M.V., Evaluation of Hemodynamic and Arterial Stifness Parameters in Women with Htais/Preeclampsia, The 17thNational Congress of the Romanian Society of Obstetrics and Gynecology, 20-22 September 2018, la-i, Romania, pag 639-643, Ed. Filodiritto Editore Proceedings, ISBN 978-88-85813-33-5

6.UTA M., PETRE I., CRAINA M., CHIRIAC V. D., STELEA L., MOLERIU L. C., POP E., IURCIUC M., STOIAN D., IVAN M.V., Correlation Between Obesity and Preeclampsia -Risk Factor for Pregnancy, The 17 National Congress of the Romanian Society of Obstetrics and Gynecology, 2022 September 2018, Ia-i, Romania, pag 833-836, Ed. Filodiritto Editore Proceedings, ISBN 978-88-85813-33-5
7.STELEA, L., PETRE, I., CRAINA, M., VLAICU, B., SISU, A., POP, E., MOLERIU, R.D., IVAN, M.V., NOVAK, T., LAZAR, F., Body Mass Index, Follicle-Stimulating Hor mone and their Predictive Value in vitro Fertilization. Rev. Chim. (Bucharest), 69, no. 7, 2018,p. 1842 - 1845 8.IVAN M.V., ZALA A., AGOP A., PUIU A., VAIDEANU A., PALAMACIUC I., IANCU D.T., CRISAN-DABIJA R., Several aspects about fractality role in the dynamics of complex systems. ISSN 1223-7027 Revista UPB, vol 79, pp 235-246

9.MUNTEANU, M., APOSTOL, A., IVAN, M.V., New Considerations Regarding Chronic Kidney Disease, Cardiovascular Disease and Dyslipidemia in Diabetic Patients, Rev. Chim. (Bucharest), 69, no. 8 2018, p. 2064-2066

10.GADALEAN F., SIMU M., PARV F., VOROVENCI R., TUDOR R., SCHILLER A., TIMAR R., PETRICA L., VELCIOV S., GLUHOVSCHI C., BOB F., MIHAESCU A., TIMAR B., SPASOVSKI G., IVAN M.V., The impact of acute kidney injury on in-hospital mortality in acute ischemic stroke patients undergoing intravenous thrombolysis. PLOS ONE Volume:12 Issuue:10 Article number:e0185589 Published:OCT 172017 11.ANDOR B., DANCIU C., ALEXA E., ZUPKO I., HOGEA E., CIOCA A., CORICOVAC D., PINZARU I., PATRASCU J., MIOC M., CRISTINA R. T., SOICA C., DEHELEAN C., Germinated and ungerminated seeds extract from two Lupinus Species: Biological Compounds Characterization and in vitro and in vivo evaluations Evidence-Based Complementary and Alternative Medicine Article ID 7638542, 2016, p. 1-8

12.ALBAI A., SIMA A., PAPAVA I., ROMAN D., ANDOR B., GAFENCU M., Associations between coping mechanisms and adherence to diabetes related self-care activities: a cross-sectional study, Patient preference and adherence Volume 11, 2017, p. 1235-1241

13.BODNAR L.M., NESS R.B., MARKOVIC N., ROBERTS J.M., The risk of preeclampsia rises with increasing prepregnancy body mass index. Ann Epidemiol. 2005;15(7):475-482.

14.BODNAR L.M., CATOV J.M., KLEBANOFF M.A., NESS R.B., ROBERTS J.M., Prepregnancy body mass index and the occurrence of severe hypertensive disorders of pregnancy. Epidemiology. 2007 Mar;18(2):234-239

15.CATOV J.M., NESS R.B., KIP K.E., OLSEN J ., Risk of early or severe pre-eclampsia related to pre-existing conditions. Int J Epidemiol. 2007;36(2):412-419.

16.DANDONA P., ALJADA A., CHAUDHURI A., MOHANTY P., GARG R., Metabolic syndrome: a comprehensive perspective based on interactions between obesity, diabetes, and inflammation. Circulation. 2005;111(11):1448-1454.

17.WOLF M., KETTYLE E., SANDLER L., ECKER J.L., ROBERTS J ., THADHANI R., Obesity and preeclampsia:the potential role of inflammation. Obstet Gynecol. 2001 Nov;98(5 Pt 1):757-762

18.BODNAR L.M., NESS R.B., HARGER G.F., ROBERTS J.M., Inflammation and triglycerides partially mediate the effect of prepregnancy body mass index on the risk of preeclampsia. Am J Epidemiol. 2005;162(12):1198-1206.

19.GRIMBLE R.F., Inflammatory status and insulin resistance. Curr Opin Clin Nutr Metab Care. 2002;5(5):551-559.

20.CONRAD K.P., MILES T.M., BENYO D.F., Circulating levels of immunoreactive cytokines in women with preeclampsia. American Journal of Reproductive Immunology (Copenhagen) 1998;40(2):102111

21.CHIRIAC D.V., HOGEA L.M., BREDICEAN A.C., REDNIC R., NUSSBAUM L.A., HOGEA G.B., GRIGORAS M.L., A rare case of Meckel-Gruber syndrome, ROMANIAN J OURNAL OF MORPHOLOGY AND EMBRYOLOGY, Volume: 58, Issue: 3, Pages: 1023-1027, Published: 2017

22. ROGOBETE AF, SANDESC D, BEDREAG OH, PAPURICA M, POPOVICI SE, BRATU T, POPOIU CM, NITU R, DRAGOMIR T, AABED HIM, IVAN MV. MicroRNA Expression is Associated with Sepsis Disorders in Critically III Polytrauma Patients. Cells. 2018;7(12):271. Published 2018 Dec 13.

Manuscript received: 13.08 .2018 